Omni-Akuatika, 17 (1):19-26, 2021
ISSN: 1858-3873 print / 2476-9347 online
Research Article
journal homepage: http://ojs.omniakuatika.net

\title{
Productivity and Distribution of Fish Aggregation Devices (FADs) In Outer Ambon Bay Waters, Indonesia
}

\section{Delly Dominggas Paulina Matrutty ${ }^{\star}$ Jacobus Bunga Paillin, Stany Rachel Siahainenia, Welem Waileruny, K Rutumalessy}

\author{
Study Program on the Utilization of Fisheries Resources, Faculty of Fisheries and Marine Sciences, Pattimura \\ University, Ambon
}

*Corresponding author: dellypaulin@yahoo.com

Received 26 December 2019; Accepted 2 June 2021; Available online 30 June 2021

\begin{abstract}
Fish Aggregation Devices (FADs) are usually used by fishermen to concentrate fish for an efficient catching activity. However, the number, distance, and distribution in the waters need to be assessed in relation to the productivity of the FADs in order to maintain the sustainability. This study was aimed to map the distribution of FADs; to analyze the distribution of species, number and size of fish associated with FADs; and to calculate FAD productivity based on distribution in the Outer Ambon Bay waters. Data was obtained by observation and interview. Field observation, including: coordinates and number of FADs, species, number and size of fish. The distance and distribution of FADs, was mapped using software (Argis web), while the productivity of FADs was analyzed base on catch per unit effort (CPUE). The result, FAD in Outer Ambon Bay waters was found 25 unit and the average distance of FAD was obtained 0.47 nautical miles, and the placement of the device was irregular. The placement pattern of FADs were generally straight to coastline. Small pelagic fish was found 7 species and the 5 of the dominant species were obtained Decapterus sp, Selar crumenophthalmus, Rastreliger sp, Sardinella sp and Selaroides sp. The species were unevenly spread at each FAD with quite varied sizes. FAD productivity showed that the highest productivity was found in the middle group FAD at Ambon Bay waters.
\end{abstract}

Keywords: Distance, size, small pelagis, productivity

\section{ABSTRAK}

Rumpon digunakan oleh nelayan untuk mengkonsentrasikan ikan sehingga mudah untuk ditangkap. Akan tetapi jika penempatan rumpon tidak memperhitungkan jarak, maka diduga akan mempengaruhi produktivitas rumpon dan dapat berdampak terhadap keberlanjutannya. Penelitian ini bertujuan untuk memetakan distribusi rumpon; menganalisis distribusi spesies, jumlah dan ukuran ikan yang tertangkap dengan pukat cincin pada rumpon, dan menganalisis produktivitas rumpon berdasarkan distribusinya di perairanTeluk Ambon Luar (TAL). Data diperoleh dengan cara observasi dan wawancara. Observasi lapangan meliputi: koordinat dan jumlah rumpon, jenis, jumlah dan ukuran ikan. Data dari jenis, jumlah dan ukuran ikan dianalsis secara deskriptif, sedangkan posisi rumpon dipetakan dengan menggunakan software (Argis web). Produktivitas rumpon dianalisis melalui pendekatan catch per unit effort (CPUE). Hasil Penelitian ini ditemukan 25 unit rumpon di Teluk Ambon Luar, dengan jarak rata-rata antara rumpon 0,47 mil laut. Pola penempatan rumpon adalah tidak beraturan. Jenis ikan pada rumpon diperoleh 7 spesies, dan spesies yang dominan diperoleh 5 spesies, yaitu: Decapterus sp, Selar cumonepthalmus, Rastreliger sp, Sardinella sp dan Selaroides sp. Spesies-spesies tersebut menyebar tidak merata pada setiap rumpon dengan ukuran cukup bervariasi. Produktivitas rumpon tertinggi diperoleh pada kelompok rumpon yang terletak di bagian tengah.

Kata Kunci: Jarak, ukuran, pelagis kecil, produktivitas.

\section{Introduction}

Fish Aggregation Device (FAD) is one of the fishing aids that widely is used in tropical and sub-tropical waters because it is quite productive in an effort to concentrate fish to make it easier to be caught by fishermen. Fishermen no longer explore for fish and fishing 
activities around the FADs is increased fishing productivity (Sudirman 2013; Nurani et al., 2014; Cabral et al., 2014). Whereas Beverly et al., (2012) stated that fishing around FAD for high value pelagic species is very effective in terms of cost and time if compared to without using FAD. The condition encourages fishermen to use FADs to increase their catches, especially The fishing target is small pelagic fish that have economic value.

The same condition was found in small pelagic fisheries by fishermen in Ambon Bay coastal. Geographically Ambon Bay water is divided into two parts, namely: Inner Ambon Bay waters (TAD: perairan Teluk Ambon Dalam) and Outer Ambon Bay waters (TAL: perairan Teluk Ambon Luar). The Outer Ambon Bay waters (TAL) is one of the areas with high potential for small pelagic fish species such as: Decapterus sp, Selar sp, Rastreliger sp, Selaroides $\mathrm{sp}$ and others. Purse Seine fisherman is fishing around FADs in the waters of Outer Ambon Bay waters. However, the catch of the purse seine tends to decrease at this time. Initial information from interviews to fishermen over the past 5 years, some of FAD in TAL are decrease in production due to increasing the number of FADs. Increasing number of FADs in this region since the government provided assistance and permission to operate FADs to facilitate the purse seiner after the humanitarian conflict in Ambon in 2004 (Tiven et al., 2018).

Local fishermen state that the aplication of FADs in the Outer Ambon Bay waters (TAL), the distance between FAD are very close (less than 1 mile), impact of the condition, fishermen difficult to choose FADs as concentrating the fish. Government have stated that the distance between FADs 10 nautical miles (Kepmen KP RI Number 26/ Permen-Kp /2014) to keep the highest of FAD productivity and the sustainability of fisheries resources for long usage. Important questions are need to answer base on scientific data of FADs that have operated in the Outer Ambon Bay waters are: How many and the distance of FADs to the other?, what is the species and sizes of fish that distributed in FAD ? and how much productivity of the FADs?.

Species of Decapterus sp, Katsuwonus pelamis and Thunnus albacares are caught around the FADs that the fish are dominated by immature and juvenile fish (Prayitno et al., 2017). The condition is due to the increasing number of FADs and fishing efforts (Davies et al., 2014). Cabral et al., (2014) stated that the use of FADs can increase the catch per unit of the vessel when the number of fishing attempts is still low. However, it can threaten the sustainability of fishery activities, if the number of fishing attempts is too high. In addition, Taquat et al., (2007) stated that the fish gathered around FADs are mostly juvenile from large pelagic fish and reef fish. These fish swim near the surface to a depth of $10 \mathrm{~m}$ and the fish in range of the depth of the purse seiner, and the fish can be easily caught by the net. The capture of immature and juvenile fish from tuna or other fish will threaten the survival of these fish species (Dagorn et al., 2012; Prayitno et al., 2017). The objectives of this study were: (1) to analyze and to map the distribution of FADs; (2) to analyze the species distribution, number and size of fish in FAD, and (3) to calculate FAD productivity in TAL.

\section{Material and methods}

The research was conducted in Outer Ambon Bay waters from July to September 2018. Field survey, interview and observation were done twice to collect the position of FADs, fish species, fish measurement, and the data are analyzed descriptive-qualitatively. FADs position are fixed using Global Positioning System (GPS) on a single longboat. The first observation, the data of FADs locations were collected and assisted by local expert long-term fishermen. The second observation: identification of fish species and fish measurement are collected from the purse seiner in each FAD as much as $10 \%$ of the total catch. Whereas to find out the productivity of FAD, data are obtained directly from the logbook of each FAD owner. The data are tabulated, analyzed and mapped towards basic map of Ambon Island waters. FAD position in Outer Ambon Bay waters is shown in Figure 2 and construction of FAD operated is shown in Figure 1. Productivity of FAD is analyzed base on Gulland 1983; Sparre and Venema 1992, as follow :

$$
P R=C r 1+C r 2 \ldots . C r n / N
$$

where:

$P R$ is Productivity of FAD,

$\mathrm{Cr}$ is CPUE of FAD (Fad $\left.{ }_{1-n}\right)$,

$\mathrm{N}$ is number of $F A D$,

CPUE is catch per unit effort (c/f),

$c$ is catch, and $f$ is effort (number of trip).

Based on the distribution of FAD position and FAD distance are divided into 6 groups, as is shown in Table 1. 


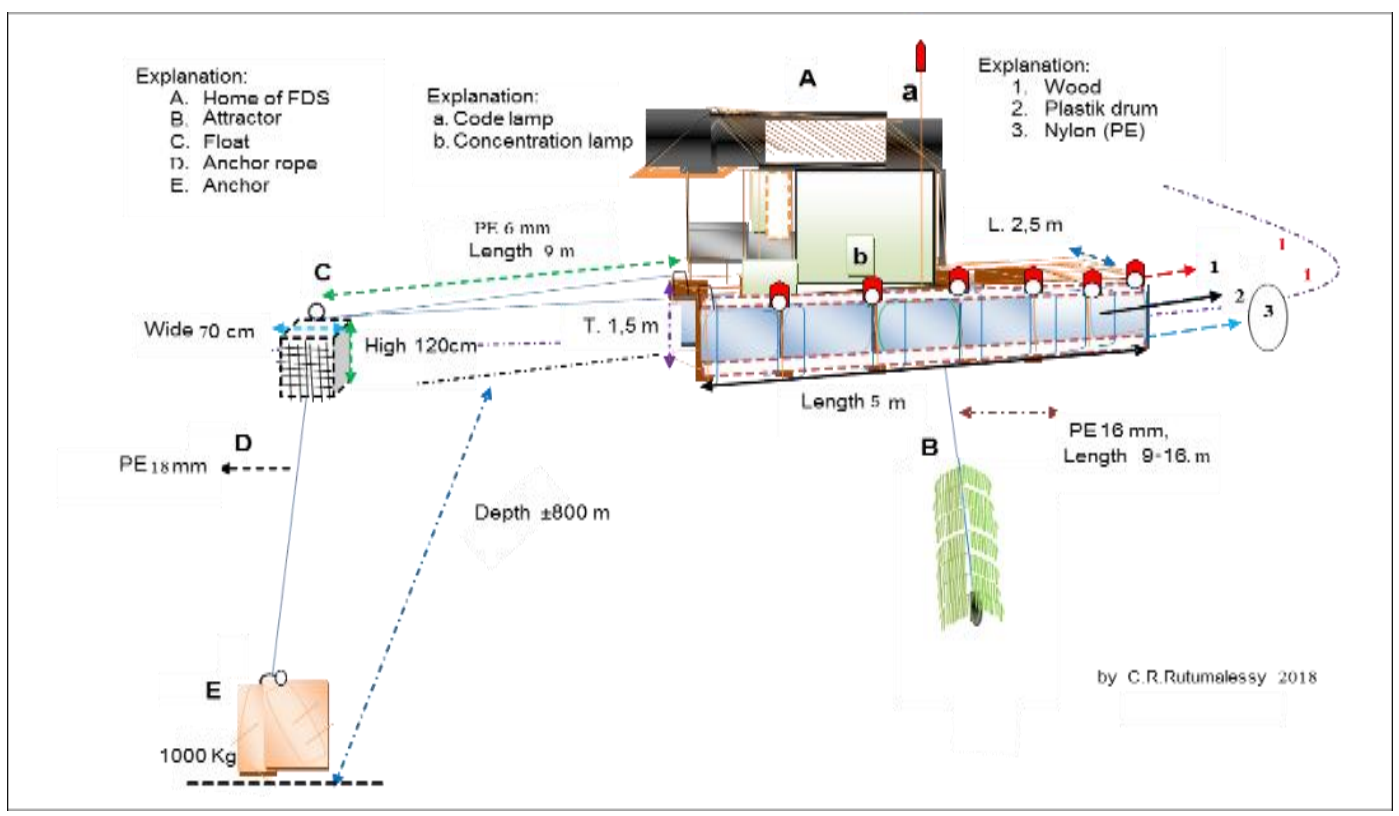

Figure 1. Construction of FAD using in Outer Ambon Bay waters

Table 1. Astronomical Position, Group and Distance of FADs in the Outer Ambon Bay waters

\begin{tabular}{|c|c|c|c|c|}
\hline \multirow{2}{*}{ No } & \multicolumn{2}{|c|}{ Position } & \multirow{2}{*}{ Group of FADs } & \multirow{2}{*}{$\begin{array}{l}\text { Distance of FAD } \\
\text { (nautical mile) }\end{array}$} \\
\hline & Latitude & Longitude & & \\
\hline 1 & $03^{\circ} 44^{\prime} 49.21^{\prime \prime} \mathrm{S}$ & $128^{\circ} 04^{\prime} 55.27^{\prime \prime} \mathrm{E}$ & Group A & $0.5-0.76$ \\
\hline 2 & $03^{\circ} 44^{\prime} 35.62^{\prime \prime S}$ & $128^{\circ} 04^{\prime} 53.37^{\prime \prime} \mathrm{E}$ & & \\
\hline 3 & $03^{\circ} 42^{\prime} 55.02^{\prime \prime S}$ & $128^{\circ} 05^{\prime} 56.71^{\prime \prime} \mathrm{E}$ & & \\
\hline 4 & $03^{\circ} 45^{\prime} 21.13^{\prime \prime} \mathrm{S}$ & $128^{\circ} 06^{\prime} 15.50^{\prime \prime} \mathrm{E}$ & Group B & $0.2-0.72$ \\
\hline 5 & $03^{\circ} 45^{\prime} 08.54^{\prime \prime} \mathrm{S}$ & $128^{\circ} 05^{\prime} 35.27^{\prime \prime} \mathrm{E}$ & & \\
\hline 6 & $03^{\circ} 43^{\prime} 54.29^{\prime \prime S}$ & $128^{\circ} 06^{\prime} 07.75^{\prime \prime} \mathrm{E}$ & & \\
\hline 7 & $03^{\circ} 44^{\prime} 26.14^{\prime \prime} \mathrm{S}$ & $128^{\circ} 06^{\prime} 08.43^{\prime \prime} \mathrm{E}$ & & \\
\hline 8 & $03^{\circ} 44^{\prime} 39.33^{\prime \prime} \mathrm{S}$ & $128^{\circ} 06^{\prime} 08.94^{\prime \prime} \mathrm{E}$ & & \\
\hline 9 & $03^{\circ} 44^{\prime} 55.38^{\prime \prime} \mathrm{S}$ & $128^{\circ} 06^{\prime} 09.66^{\prime \prime} \mathrm{E}$ & & \\
\hline 10 & $03^{\circ} 45^{\prime} 08.47^{\prime \prime} \mathrm{S}$ & $128^{\circ} 06^{\prime} 11.03^{\prime \prime} \mathrm{E}$ & & \\
\hline 11 & $03^{\circ} 45^{\prime} 03.85^{\prime \prime} \mathrm{S}$ & $128^{\circ} 06^{\prime} 01.95^{\prime \prime} \mathrm{E}$ & & \\
\hline 12 & $03^{\circ} 43^{\prime} 41.60^{\prime \prime} \mathrm{S}$ & $128^{\circ} 07^{\prime} 09.88^{\prime \prime} \mathrm{E}$ & Group C & $0.40-0.56$ \\
\hline 13 & $03^{\circ} 43^{\prime} 30.62^{\prime \prime} \mathrm{S}$ & $128^{\circ} 06^{\prime} 06.12^{\prime \prime} \mathrm{E}$ & & \\
\hline 14 & $03^{\circ} 42^{\prime} 34.12^{\prime \prime} \mathrm{S}$ & $128^{\circ} 07^{\prime} 59.95^{\prime \prime} \mathrm{E}$ & Group D & \\
\hline 15 & $03^{\circ} 43^{\prime} 35.69^{\prime \prime} \mathrm{S}$ & $128^{\circ} 07^{\prime} 00.00^{\prime \prime} \mathrm{E}$ & & $0.05-0.20$ \\
\hline 16 & $03^{\circ} 43^{\prime} 37.96^{\prime \prime} \mathrm{S}$ & $128^{\circ} 07^{\prime} 03.39^{\prime \prime} \mathrm{E}$ & & \\
\hline 17 & $03^{\circ} 42^{\prime} 33.56^{\prime \prime} \mathrm{S}$ & $128^{\circ} 07^{\prime} 56.79^{\prime \prime} \mathrm{E}$ & Group E & $0.05-0.07$ \\
\hline 18 & $03^{\circ} 42^{\prime} 39.61^{\prime \prime} \mathrm{S}$ & $128^{\circ} 08^{\prime} 10.89^{\prime \prime} \mathrm{E}$ & & \\
\hline 19 & $03^{\circ} 42^{\prime} 55.42^{\prime \prime} \mathrm{S}$ & $128^{\circ} 08^{\prime} 27.37^{\prime \prime} \mathrm{E}$ & & \\
\hline 20 & $03^{\circ} 42^{\prime} 32.01^{\prime \prime} \mathrm{S}$ & $128^{\circ} 08^{\prime} 20.87^{\prime \prime} \mathrm{E}$ & & \\
\hline 21 & $03^{\circ} 42^{\prime} 33.31^{\prime \prime} \mathrm{S}$ & $128^{\circ} 07^{\prime} 56.27^{\prime \prime} \mathrm{E}$ & & \\
\hline 22 & $03^{\circ} 42^{\prime} 55.42^{\prime \prime} \mathrm{S}$ & $128^{\circ} 08^{\prime} 27.37^{\prime \prime} \mathrm{E}$ & & \\
\hline 23 & $03^{\circ} 44^{\prime} 07.49^{\prime \prime} \mathrm{S}$ & $128^{\circ} 04^{\prime} 51.31^{\prime \prime} \mathrm{E}$ & Group F & $0.69-0.86$ \\
\hline 24 & $03^{\circ} 41^{\prime} 37.63^{\prime \prime} \mathrm{S}$ & $128^{\circ} 08^{\prime} 12.78^{\prime \prime} \mathrm{E}$ & & \\
\hline 25 & $03^{\circ} 41^{\prime} 56.94^{\prime \prime} \mathrm{S}$ & $128^{\circ} 08^{\prime} 12.43^{\prime \prime} \mathrm{E}$ & & \\
\hline
\end{tabular}




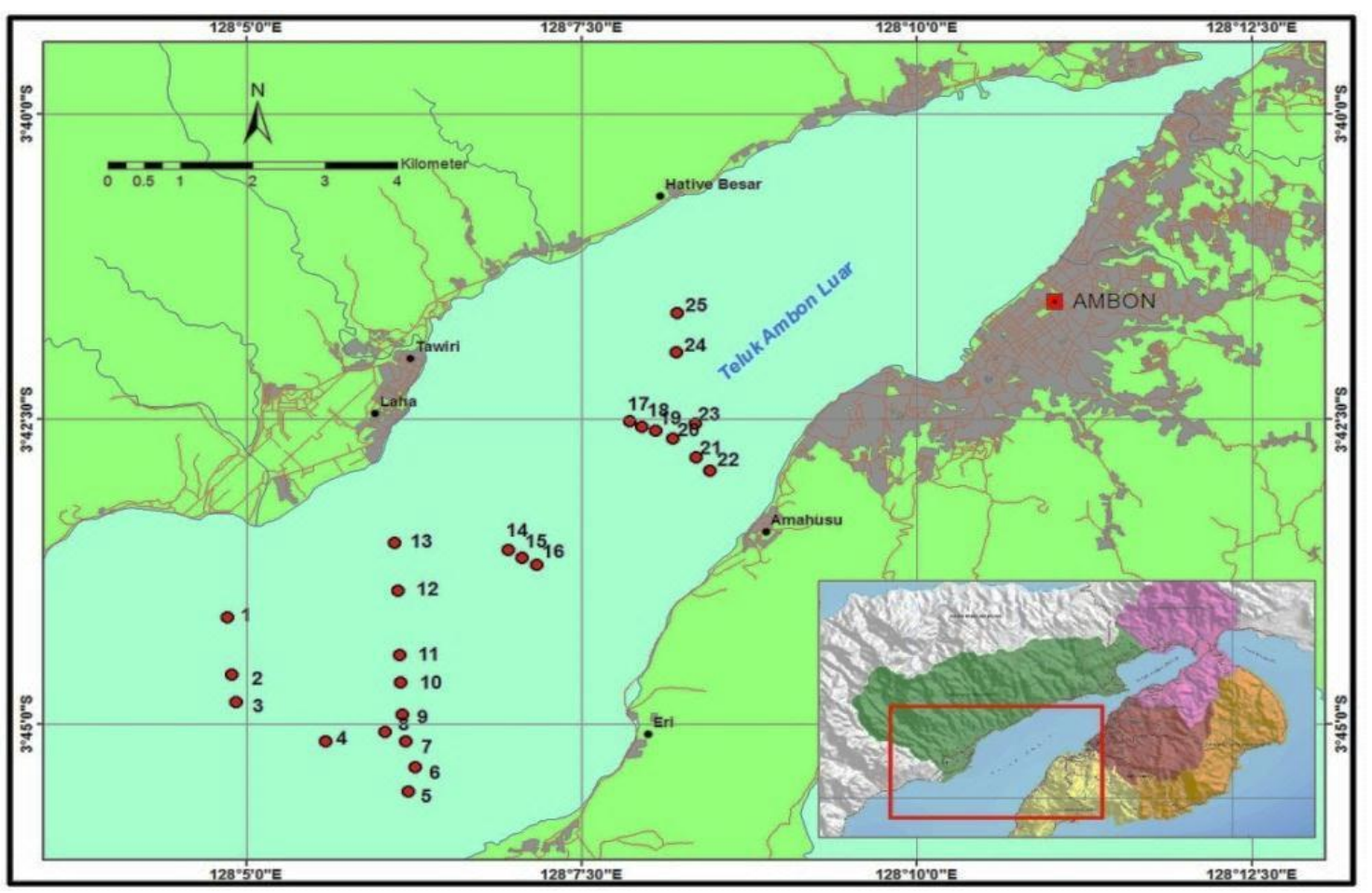

Figure 2. Map of distribution of 25 FADs in Outer Ambon Bay waters

\section{Results and Discussions}

\subsection{Distribution of FADs}

Total number of FADs at the Outer Ambon Bay waters (TAL: Teluk Ambon Luar) was found 25 units. Those FADs were belong to the fishermen from Laha and Hative Besar, Teluk Ambon District. The position of FADs from seaside to Ambon Bay waters were show that the FADs position between $128^{\circ} 04$ '55.27' '$128^{\circ} 04^{\prime}$ ' 51.31 " E and $03^{\circ} 44$ '49.21 "- $03^{\circ} 44^{\prime}$ 07.49 " S (Fig. 2). FADs were fixed at depth of 400-700 m. The distance of FAD to other were very close, i.e. between $0.05-0.86$ nautical miles and the average distance was found 0.47 nautical miles, whereas the position distribution pattern of FADs were obtained irregular. Some FADs or group of FAD were placed straight to the coastline and some FADs were seemed to form a group in irregular pattern (Fig. 2). Referring to the Minister of Maritime Affairs and Fisheries Regulation No. 26 / PERMEN-KP / 2014, the distribution of FADs in TAL waters, especially the distance and the distribution pattern were shown contrary to the intended regulation. The distance between FADs based on the regulation is 10 nautical miles and the placement pattern does not produce a fencing effect to the fish migration.

\subsection{Distribution of Species, Amount and Size of Fish}

The waters of Ambon Bay was a fertile habitat for various of small pelagic fish species, the water was directly influenced by Banda Sea, Arafura Sea. Zamroni et al (2014) stated that the main habitat of mackerel scad is in deep ocean waters which form a large groups in the surface layer. Scads (Decapterus sp) from Ambon waters is caught throughout the year (Sangaji et al (2014); Ongkers et al 2016). The species is caught by purse seiner that operated near FADs and the fish was as dominant species that catch from Ambon waters by fisherman (Silooy et al, 2019). As well, big eye scad (Selar $s p$ ) is dominant fish species that catch by drift gillnetter in Inner Ambon Bay waters (Matrutty et al 2019). The condition is suspected that the difference of the presence of small pelagic fish in FADs from Outer Ambon Bay waters was influenced by season (Figure $3)$.

Two of fish species, namely scads (Decapterus sp) and big eye scad (Selar crumenopthalmus), the fishes were often appear and dominate inhabit in the Ambon waters. The difference of species distribution and number of fish in FADs in TAL were not impact from technical factors. The number of FADs or the distance of FADs that very close to 


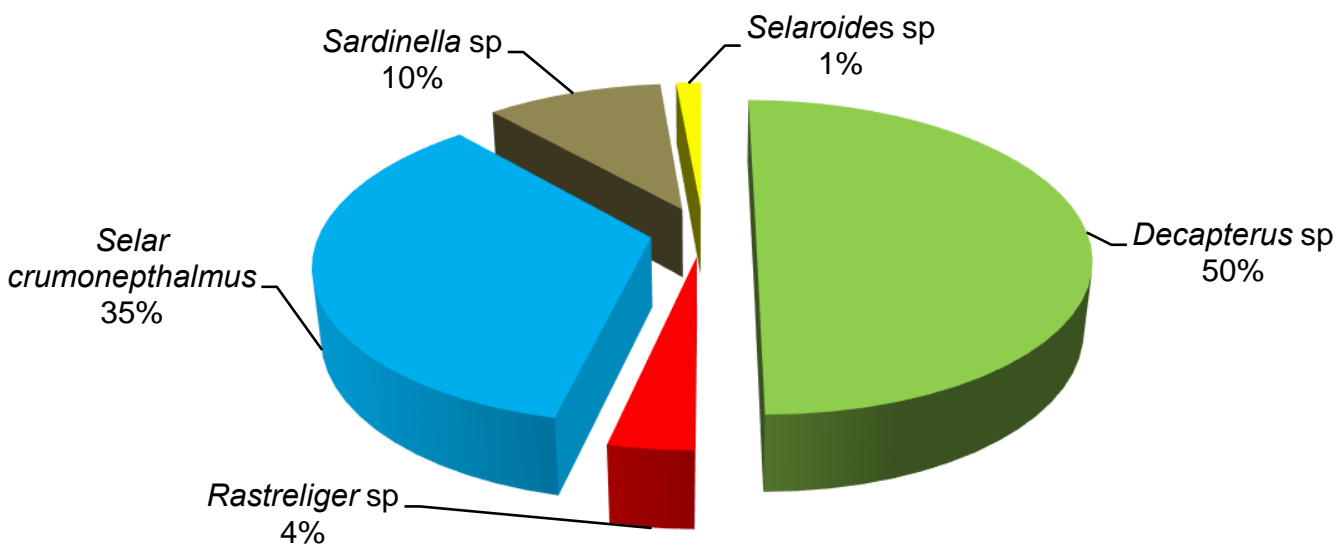

Figure 3. Percentage of fish species from FADs by purse seiner in the Outer Ambon Bay waters.

Table 2. Distribution of Fish Lengths in FADs.

\begin{tabular}{|c|c|c|c|c|c|}
\hline \multirow{2}{*}{ Period } & \multirow[b]{2}{*}{$\mathbf{n}$} & \multicolumn{2}{|c|}{ Fish Length (cm) } & \multirow{2}{*}{ Average } & \multirow{2}{*}{ sd } \\
\hline & & $\max$ & $\min$ & & \\
\hline \multicolumn{6}{|l|}{ Juli } \\
\hline Decapterus sp & 76 & 20.4 & 14.5 & 18.4 & 1.39 \\
\hline Rastreliger sp & 63 & 19.5 & 16.2 & 17.7 & 0.96 \\
\hline Selar crumonepthalmus & 59 & 18 & 14.8 & 16.65 & 0.76 \\
\hline Selaroides sp & 50 & 21.5 & 16 & 19.59 & 1.76 \\
\hline \multicolumn{6}{|l|}{ Agustus } \\
\hline Decapterus sp & 146 & 24.5 & 8.4 & 16 & $4.09^{*}$ \\
\hline Rastreliger sp & 45 & 21.5 & 10.8 & 15.93 & 3.87 \\
\hline Selar crumonepthalmus & 74 & 19.5 & 14.9 & 17.05 & 0.89 \\
\hline Selaroides sp & 46 & 21.5 & 17.1 & 16.15 & 0.46 \\
\hline \multicolumn{6}{|l|}{ September } \\
\hline Decapterus sp & 56 & 21.5 & 17.1 & 18.82 & 3.35 \\
\hline Rastreliger sp & 41 & 24.7 & 20 & 21.61 & 1.68 \\
\hline Selar crumonepthalmus & 49 & 21.6 & 14.7 & 16.71 & 2.11 \\
\hline Selaroides sp & 76 & 23.5 & 17 & 19.38 & 1.33 \\
\hline
\end{tabular}

each other and the installation pattern were suspected affect to fish migration. The factor was greatly affect to the productivity of the FADs, Simbolon et al. (2013) stated that the management of FADs by the government is intended to increase production. The development as FAD management, some problem such as irregular installation of FADs and location of FADs placement that near of each to the other have impact to the fish migration patterns. The other side, disrupting the ecological balance and impacting overfishing were impact to fish migration. Based on the total fish catch, Decapterus sp was as dominant species, namely 103,136 fishes or $31.58 \%$. The fish species was always catch throughout the year from Ambon Island waters. According to fishermen information, these fish species were always caught yearly, while the presence of Selar Crumenophthalmus,
Sardinella sp., Rastreliger sp., and Selaroides $\mathrm{sp}$. were greatly influenced by the season. The monthly fish size for each fish species was found differ (July, August, September), (Table 2).

The distribution of fish length (Table 2), if compared with some previous research and the fishes were caught with purse seiner in FADs at Outer Ambon Bay waters was categorized as adult fish, and the fish have passed of the size of the first matured gonad, namely Decapterus ruselii (Ongkers et al 2016), based on the regulations, the fishes were feasible to be caught, whereas the average length of Rastreliger $\mathrm{sp}$ on July and September were obtained less than $24 \mathrm{~cm}$ or the fish length was not reach the size of the first matured gonad. According to Mosse and Hutubessy (1996) that first maturity gonad of Rastreliger $\mathrm{sp}$ is $24 \mathrm{~cm}$. The fish length variations were highly 
dependent on seasons, populations, and dynamic of environmental conditions (Froese, 2006). Meanwhile, according to Kimmerer et al (2005) that the variation of fish length between location and sampling time is important and cannot be ignored in the application of the length-weight relationship of fish.

The average length of scad (Decapterus $\mathrm{sp)}$ that caught in FADs at Outer Ambon Bay waters was obtained between $16-18.82 \mathrm{~cm}$. The fish length was demonstrated that the fish length have exceeded to the size of the first matured gonad, according to that gonad standard that have approved in several previous research. Ongkers et al. (2017) showed that Decapterus ruselii that catch by purse seine in Latuhalat, Ambon Island that the first gonad maturity and the longest of length was represented $17.4 \mathrm{~cm}$ for female and 14.5 $\mathrm{cm}$ for male. Widodo (1988) ) said that Decapterus sp in the Java Sea that first matured is $13.9 \mathrm{~cm}$ of length and $14.8 \mathrm{~cm}$ as the catch size. Prihatini et al. (2006) also mentioned that the length of Decapterus $\mathrm{sp}$ is $14.0 \mathrm{~cm}$ and the mature for the first time because it has reached the maturity level of the third gonad.

The average length Selaroides sp that captured in FADs at TAL waters was obtained between 16.15 to $19.59 \mathrm{~cm}$. The range of length was indicate that fish was exceeded to the size of the first adult gonads. Size and GML of Selaroides leptolepis from the Sunda Strait (Suciati, 2013) and Andriani et al. (2015) from Pemalang-Banten Regency waters are 15.7 $\mathrm{cm}$. According to Hestiana et al. (2019) that the size of first gonad maturity of Selaroides leptolepis for female is $11.8 \mathrm{~cm}$ and $14.0 \mathrm{~cm}$ for male. Yusfiandayani et al. (2015), mentioned that the FAD management for responsible fisheries should consider the aspect of fish biology from the location, fishing gear, social and economic.

FAD productivity was determined based on catch per unit effort (CPUE) of each FAD group $(A, B, C, D, E$, and F) (Figure 4). The highest CPUE value of FAD was obtained group $D$ (117.78) that the location of the FAD at the middle group of FAD at LAT waters. CPUE of FAD in group B was 83.19; CPUE group C (75.75) and CPUE group E (74.26). The lowest value of CPUE of FAD was obtained for groups $F$ (19.52). The productivity of FADs as CPUE of each group of FADs was found varies, which the middle FAD groups was obtained as the highest productivity, if the group was compared to the outer and inner at LAT waters. The phenomenon was indicated that the migration of small pelagic fish from sea move to the Ambon Bay waters and stay in outer of FADs group, then most of fish are move and concentrate in the middle group of FADs at the Ambon Bay waters, and the position pattern of FAD was tend irregular. Based on government regulation (Kepmentan Nomor 51/KPTS/IK.250/1/1997 ayat $f$ ) that the irregular pattern of $F A D$ is impact to the sustainability of pelagic fish. We suspected that the location of FADs and middle group of $F A D$ are the migration route of pelagic fish from sea to Ambon Bay waters.

Yusfiandayani (2013) states that the use of FADs are impact to increase the effectiveness, efficiency and importance to regulate of fishing activities, and furthermore is stated that FADs affect to the fish capture ability of fish

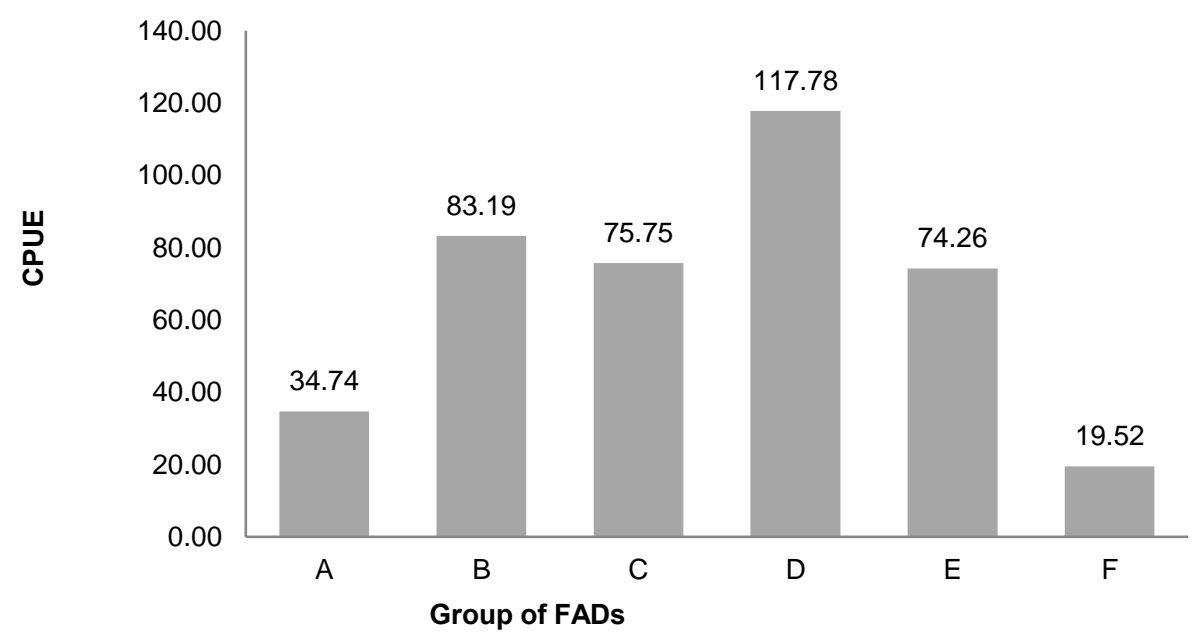

Figure 4. Distribution group of FADs productivity based on CPUE values in Outer Ambon Bay waters 
abundance. Another impact that the fish stock become more vulnerable to overfishing (Mathews and Monintja 1996). Therefore, it is necessary to notice and to manage of FADs in TAL waters, in order to maintain the efficiency and effectiveness of small pelagic fisheries activity, as well as to develop the FAD and purse seine fisheries business at Ambon waters.

\section{Conclusions}

The highest productivity of FAD was found at middle group of FAD than at Outer and Inner group of FAD at Ambon Bay waters. The FAD installation was obtained irregular and is not according to government regulations, that the distance of the FAD was less than 10 nautical miles. To create sustainability fisheries, high productivity of FAD, high of fish catch and the fishing business remains sustainable, the installation of FAD should pay attention to the migration route of the small pelagic fish resources.

\section{Acknowledgment}

Thank you to the Dean of the Faculty of Fisheries and Marine Sciences Pattimura University and Ristekdikti for providing research funding and also to Kristo who assisted in data collection.

\section{Suggestion}

FADs in the Outer Ambon Bay need to be managed properly, for instance the number of FADs, proximity and installation patterns in order to maintain the sustainability of fishing activities in Ambon Bay, especially focusing on small pelagics.

\section{REFERENCES}

Andriani, N., Saputra, S., Hendrarto, B. 2015. Biological Aspects and Level of Utilization of Selaroides leptolepis fish species caught in cantrang nets in the waters of Pemalang Regency. Diponegoro Journal Of Maquares vol 4 (4): 24-32.

Beverly, S., Griffiths, D., Robert, L. 2012. Anchored fish aggregating devices for artisanal fisheries in South and Southeast Ase: benafits and risks. The Food and Agriculture Organization of the United Nation Regional Office For Asia and Pacific. Bangkok, Thailand, 65p.

Cabral, R.B., Aliño, P.M., and Lim, M.T. 2014. Modelling the Impacts of Fish Aggregating Devices (FADs) and Fish Enhancing
Devices (FEDs) and Their Implications for Managing Small-Scale Fishery. ICES Journal of Marine Science 71(7): 17501759.

https://doi.org/10.1093/icesjms/fst229

Dagorn, L., Holland, K.N., Restrepo, V., Moreno, G. 2012. Is It Good or Bad to Fish with FADs? What are the Real Impacts of the Use of Drifting FADs on Pelagic Marine Ecosystems?. Fish and Fisheries. 14(3): 391-415.

Davies, T.K, Mees, C.C., Gulland, E.J.M. 2014. The Past, Present and Future Use of Drifting Fish Aggregating Devices (FADs) in the Indian Ocean. Marine Policy. 45: 163170.

Froese, R. 2006. Cube law, condition factor and weight-length relationships: History, metaanalysis and recommendations. Journal of Applied Ichthyology, vol 22(4): 241-253. https://doi.org/10.1111/j.14390426.2006.00 805.x.

Hestiana, Yasidi, F., Mustafa, A. 2019. Biology of reproduction of yellowstripe Scard (Selaroides leptolepis). Jurnal Manajemen Sumber Daya Perairan 4 (1): 23-30.

Kimmerer, W., Avent, S.R., Bollens, S.M., Feyrer, F., Grimaldo, L.F., Moyle, P.B., Nobriga, M., Visintainer, T. 2005. Variability in length-weight relationships used to estimate biomass of estuarine fish from survey data. Transactions of the American Fisheries Society, vol 134(2): 481-495. https://doi.org/10.1577/t04-042.1.

Matrutty, D.D.P., Matakupan, H., Waileruny W., Tamaela L. 2019. Productivity of Drift Gillnet Based On The Time Spent Fishing In The Inner Ambon Bay in Waileruny et al. National Conference of the Fisheries and Marine science Faculty. https://doi.org/10.30598/semnaskp-14.

Mathews, C.P., Monintja, D.R. 1996. Assessment of the Role of foreign and Industrial Tuna Fishing in Indonesia's EEZ, Archipelagic and Territorial Waters. Report Central Research Institute for Fisheries Research, Jakarta.

Mosse, J. W and Hutubessy, B. G. 1996. Age, growth and first size of gonad maturity of Rastreliger kanagurta from Ambon Islands and surrounding waters. J. GOTI, Pattimura University vol 1(1). 
Nurani, T.W., Sugeng, H.W., Wahyuningrum, P.I., Arhatin, R.E. 2014. The FAD Development Model as a Tool in the Sustainable Utilization of Tuna Resources. Jurnal IImu Pertanian Indonesia (JIPI) Vol 19 (1): 57-65.

Ongkers, T., Pattikawa, J.A., Rijoly, F. 2016. Biological aspects of ikan layang (Decapterus ruselii) in Latuhalat waters, Nusaniwe District, Ambon Island. J OmniAkuatika Vol 12 (3): 79-87.

Prayitno, M.R. E., Simbolon, D., Yusfiandayani, R., Wiryawan, B. 2017. Productivity of Fishing Gears Operated Around Deep Sea Fish Aggregating Devices. J Marine Fisheries Vol 8 (1): 101-112.

Prihatini, A.,Anggoro, S., and Asriyanto. 2006. Analysis of Biological conditions of ikan layang (Decapterus spp) caught by Purse Seine landed at PPN Pekalongan. Journal of Pasir Laut Vol 3 (1) :61-75.

Sangadji, J., Kusumastanto T., simanjuntak, H.S.M. .2014. Depreciation Analysis and Management Policy of Scad (Decapterus $s p)$ Resources in Ambon City Waters.

Silooy, F.D., Tupamahu, A., Ongkers O.T.S., Matrutty, D.D.P. 2019. Size Distribution and Growth Mackerel scad (Decapterus macarellus) in the Ambon Waters. International Journal of Environment, Agriculture and Biotechnology (IJEAB) vol 4 (2): 505-508.

Simbolon et. al. 2009. Establishment of a Fishing Area. Department of Fisheries Resource Utilization of IPB. Bogor. $168 \mathrm{p}$

Suciati, L. 2014. Study of Stock Stocks of Selar ekor kuning (Selaroides leptolepis) (Cuvier 1833) in the Sunda Strait Waters which was landed at PPP Labuan Banten. [Thesis]. Management of Water Resources, Faculty of Fisheries and Marine Sciences. Bogor Agricultural Institute. Bogor.
Sudirman, H. 2013. Knowing the Fsihing Gear and Methods. PT. Rineka Cipta. Jakarta $273 \mathrm{pp}$.

Taquet, M., Sancho, G., Dagorn, L., Gaertner. J.C., Itano, D., Aumeeruddy, R., Wendling, B., Peignon, C. 2007. Characterizing Fish Communities Associated with Drifting Fish Aggregating Devices (FADs) in the Western Indian Ocean Using Underwater Visual Surveys. J Aquatic Living Resources Vol 20 (4): 331-341. DOI: https://doi.org/10.1051/alr:2008007

Tiven, M, Huliselan N.V, Lopulalan Y. 2018. Effektiveness of fishermen card pollicies in Ambon City. Jurnal Triton 14 (2): 76-87.

Widodo, J. 1988. Population dynamics and management of ikan layang, scad mackerel, Decapterus spp (Pisces: Carangidae) in the Java Sea. Ph.D. dissertation, University of Washington, 155pp.

Yusfiandayani, R. 2013. Fish Aggregating Devices In Indonesia: Past And Present Status on sustainable capture fisheries. Galaxea, J of Coral Reef Studies (Special Issue): 260-268. $36 \mathrm{pp}$

Yusfiandayani, R., Baskoro, M.S., Monintja, D. 2015. Impact of fish aggregating device on sustainable capture fisheries Vol 1 (2015). Published by knowledge E Pulishing services. Oppen acces article (http://creativecommons.org licenses/bync-nd/4.0). DOI: http://dx.doi.org/10 18502/kls.v li0.107.

Zamroni, A., Suwarsono., Nugroho, E. 1914. Genetic Structure Of Mackerel Scad Populations (Decapterus Macarellus Cuvier, 1833) around Sulawesi Based On Mt-Dna Marker J. Lit. Perikan. Ind. Vol.20 (1): 31-41. 